\title{
Evaluatie van een multimodale behandeling voor kleuters met ernstige gedragsproblemen
}

Anneloes van Brussel, Ronald De Meyer, Jan Willem Veerman en Wim De Mey

\begin{abstract}
SAMENVATTING
Dit artikel presenteert de effecten van Samen Sterker Terug Op Pad (sтop4-7), een in Vlaanderen ontwikkeld multimodaal gedragstherapeutisch programma voor kinderen met ernstige gedragsproblemen. Het onderzoek laat zien dat kinderen en ouders die het programma volgen, vooruitgang boeken. Na de behandeling vertonen de kinderen volgens de ouders significant minder externaliserend, minder internaliserend en meer prosociaal gedrag. Het externaliserende gedrag blijft echter voor veel kinderen $(60 \%)$ in de klinische range. Ouders zijn meer consequent in hun opvoeden en ervaren minder opvoedingsbelasting. Leerkrachten zien weinig vooruitgang op externaliserend gedrag, maar wel op internaliserend en prosociaal gedrag. De gevonden effecten zijn voor het merendeel klein tot middelgroot.
\end{abstract}

\section{Inleiding}

Antisociaal gedrag, waarbij de grondrechten van anderen of belangrijke bij de leeftijd horende sociale normen of regels worden overtreden, vormt een ernstig probleem in onze maatschappij. Het komt steeds meer voor, zorgt voor een onveilig gevoel en het brengt hoge kosten met zich mee (Scott, Knapp, Henderson \& Maughan, 200I). Onderzoek over het ontwikkelingsverloop van dit gedrag brengt aan het licht dat hoe eerder het zich ontwikkelt, hoe groter de kans is op ernstige problemen gedurende de adolescentie en volwassenheid (Loeber, Slot \& Sergeant, 200I). Kinderen die het meeste risico lopen om in de adolescentie in aanraking te komen met antisociale gedragingen als delinquentie en drugsgebruik, zijn merendeels dezelfde kinderen die

Drs. A. van Brussel is klinisch psycholoog bij Entréa te Nijmegen. Tijdens het onderzoek was zij werkzaam bij Praktikon (onderdeel van Entréa). Contactadres: Entréa, Postbus 6731, 6503 GE Nijmegen. E-mail: a.vanbrussel@entrea.nl.

Dr. R. E. De Meyer is onderzoeker bij Praktikon te Nijmegen.

Prof. dr. J. W. Veerman is bijzonder hoogleraar speciale kinder- en jeugdzorg aan de Radboud Universiteit Nijmegen en hoofd van Praktikon te Nijmegen.

Drs. W. De Mey is praktijklector aan de Universiteit Gent. Hij is tevens coördinator van het stop-team. 
op jonge leeftijd ernstige gedragsproblemen lieten zien (Webster-Stratton \& Taylor, 200I).

Campbell (I995) wijst erop dat gedurende de peutertijd (2,5-4 jaar) opstandig en ongehoorzaam gedrag normaal is. Het zijn echter de kinderen die na deze periode dit gedrag blijven vertonen, die onze aandacht verdienen. Zij kampen met meer of minder ernstige gedragsproblemen. Niet alle jonge kinderen met gedragsproblemen gaan later in de adolescentie antisociaal gedrag vertonen. Het is vooral de aanwezigheid van dwinggedrag ('coercive behaviour') en van een accumulatie van risicofactoren, die de kans op blijvende gedragsproblemen doen toenemen. De spiraal van coërcief gedrag, bestaande uit aversieve interacties in de tijd, waarbij ouders en kinderen elkaar wederzijds negatief bekrachtigen, is duidelijk een van de vroegste en meest krachtige antecedenten van later antisociaal gedrag. Deze cirkel vormt ook de basis van de sociale leertheorie van Patterson (Patterson, I982; Patterson, 2002; Patterson, Reid \& Dishion, I992).

Ouders bekrachtigen een kind door het zijn zin te geven, kinderen bekrachtigen hun ouders door zich rustig te gedragen als zij hun zin hebben gekregen. Door dit leerproces missen deze kinderen bij de aanvang van hun schoolloopbaan belangrijke vaardigheden, zoals het delen van aandacht, rekening houden met anderen, samenspelen, maar ook volhouden en iets afmaken. Deze kinderen lopen ook meer risico's op problemen in relaties met leeftijdgenoten en in het bijzonder op een actieve afwijzing door hun leeftijdgenoten (Dodge e.a., 2003). In de loop van de basisschool vinden deze kinderen vaak aansluiting bij anderen met eenzelfde ontwikkelingsverloop. Ze gaan elkaar wederzijds versterken in aanvankelijk licht maar later steeds ernstiger antisociaal gedrag. Wanneer kinderen deze fase in de antisociale ontwikkeling bereiken, wordt de invloed van volwassenen steeds kleiner en is het gedrag steeds moeilijker te corrigeren.

Dishion, French en Patterson (I995) wijzen erop dat in de ontwikkeling van antisociaal gedrag biologische of neurologische factoren een rol spelen (zoals tekorten in het verbale en executieve functioneren), evenals temperamentskenmerken, sociaalcognitieve vaardigheden bij het kind en proximale omgevingsfactoren (opvoedingsvaardigheden, relationele factoren, sociale steun) en distale omgevingsfactoren (sociaal-economische status buurt, behoren tot een ethnische minderheid, de economische en politieke situatie). Van de Wiel (2002) voegt hier nog aan toe dat antisociaal en agressief gedrag niet alleen geleerd wordt vanuit de consequenties die volgen op het gedrag, maar ook door het waarnemen van opstandige, agressieve en antisociale modellen. Voorts blijkt dat kinderen die dit gedrag vertonen over gebrekkige mogelijkheden beschikken om sociale signalen op te vangen en te interpreteren (Orobio de Castro, Veerman, Koops, Bosch \& Monshouwer, 2002). Zij gaan in sociale situaties weinig op zoek naar feiten en denken al gauw dat anderen vijandige bedoelingen hebben. Voor sociale problemen bedenken ze minder oplossingen en vaker een agressieve oplossing.

Hoewel uit het bovenstaande duidelijk wordt dat antisociaal gedrag multifactorieel bepaald is, blijkt uit verschillende literatuuroverzichten dat een oudertraining op basis van de sociale leertheorie en cognitieve-gedragstherapeutische interventies het meest behulpzaam is bij preventie en behandeling van dit gedrag, alsook van de gedrags- 
problemen die hiervan als voorloper worden gezien (Brestan \& Eyberg, I998; Kazdin \& Weisz, I998; Lundahl, Risser \& Lovejoy, 2005; Webster-Stratton, \& Hammond, I997; Webster-Stratton \& Taylor, 200I). Multimodale programma's waarbij naast ouders ook het kind en de leerkracht betrokken worden, blijken effectiever dan programma's die zich richten op alleen de ouders, kinderen of leerkrachten.

Een multimodale behandeling voor jonge kinderen met ernstige gedragproblemen was in Nederland nog niet voorhanden. Het in Vlaanderen ontwikkelde programma Samen Sterker Terug Op Pad (sто 4-7; De Mey, 2005) werd gekozen om in Nederland te implementeren en op zijn effect te onderzoeken door Entréa/PI-school te Nijmegen (instelling voor jeugdzorg, onderwijs en onderzoek), Trajectum te Zeist (instelling voor jeugdzorg), Praktikon te Nijmegen (organisatie voor onderzoek en ontwikkeling in de jeugdzorg, verbonden aan Entréa) en het Nederlands Jeugdinstituut te Utrecht (NJI, voorheen NIZw). Het programma (gericht op 4-7-jarigen) is op zijn beurt weer een aanpassing van het Amerikaanse, uit de 'Patterson-school' voortkomende, Linking the Interests of Families and Teachers (LIFT; zie Eddy, Reid \& Fetrow, 2000) aan de Vlaamse situatie (De Mey, 2000).

In een literatuurstudie van Delicat (2003) naar multimodale programma's voor viertot zevenjarige 'opstandige' kinderen bleek het LIFT-programma een van de effectieve interventies. Uit follow-up-onderzoek blijkt dat er gunstige verschillen zijn tussen de interventie- en controlegroep op het gebied van alcoholgebruik, optrekken met probleemjongeren en arrestaties.

\section{STOP 4-7}

De doelgroep van STOP4-7 bestaat uit kinderen van vier tot en met zeven jaar en hun opvoeders. Het gaat om kinderen met ernstige gedragsproblemen zoals liegen, vechten, driftbuien, ongehoorzaamheid en opstandig gedrag. Er is sprake van een coërcieve interactie (dwinggedrag) tussen ouder en kind, waardoor er geen gezagsrelatie ontwikkeld is. De ouders hebben onvoldoende opvoedingscompetenties en ervaren een hoge opvoedingsbelasting. Het programma sTo 4-7 is gebaseerd op leertheoretische principes zoals geformuleerd door het Oregon Social Learning Center van Patterson (voor een recente beschouwing zie Reid, Patterson \& Snyder, 2002). Het is een multimodale interventie, bestaande uit een groepstraining voor kinderen, ouders en leerkrachten. De interventie kent een protocol waarin de doelstellingen en methoden per bijeenkomst nauwkeurig omschreven worden. Dit protocol dient systematisch aangevuld te worden met een aantal huis- en schoolbezoeken. Hierin zit de verfijning op maat (De Mey, 2005).

De kindtraining vindt plaats gedurende tien weken, één dag per week en in een groep van vier tot acht kinderen. De activiteiten verschillen niet veel van die in een gewone kleuterklas. Het verschil zit in de gedragstherapeutische attitude van de trainers (leerkrachten en/of pedagogisch medewerkers) en de gerichtheid om vaardigheden aan te leren. Met behulp van opvoedingsvaardigheden - zoals positieve bekrachtiging (complimenten, belonen), modelling, negeren en time-out - wordt gewenst gedrag versterkt en ongewenst gedrag verzwakt. In de training wordt de kinderen gewenst gedrag aangeleerd, zoals gevoelens herkennen en benoemen, rekening houden met de ander, 
problemen oplossen, zelfcontrole (sociaal-cognitieve vaardigheden), luisteren en samenspelen.

De oudertraining bestaat uit tien wekelijkse groepssessies van twee uur en beoogt het vergroten van de opvoedingsvaardigheden van de ouders. Aan de orde komen onder meer operante leerprincipes, modelling, complimenten geven, beloningssystemen, grenzen stellen, negeren en time-out, en actief luisteren. Ouders worden aangemoedigd zoveel mogelijk zelf te proberen en te oefenen.

De leerkrachten (en indien wenselijk andere opvoeders van het kind, zoals groepsleiders) krijgen vier sessies waarin een vergelijkbaar programma wordt doorlopen als bij de ouders. Er wordt ook uitgebreid stilgestaan bij de vaardigheden die de kinderen hebben geleerd.

\section{Onderzoeksvragen}

In dit artikel wordt verslag gedaan van de eerste resultaten van de sTOP4-7-training in Nederland. Op basis van de literatuur en de theoretische onderbouwing van de training worden positieve veranderingen bij kinderen en ouders verwacht. De eerste vraagstelling kan daarom als volgt geformuleerd worden: is sтор4-7 effectief? Verminderen de gedragsproblemen van kinderen die sTop4-7 gevolgd hebben? Verbeteren de opvoedingsvaardigheden van de ouders? En vermindert de ervaren opvoedingsbelasting?

Een tweede vraagstelling heeft te maken met het stellen van een goede indicatie voor STOP4-7. Daarom is het van belang om te weten welke kinderen het meest profiteren van de behandeling en welke kinderen er het minst baat bij hebben. De hier onderzochte prognostische factoren zijn afgeleid uit wetenschappelijk onderzoek en waar mogelijk aangevuld met praktijkervaring van de trainers. Zo hebben zij gedurende het onderzoek de indruk gekregen dat de intelligentere kinderen sneller de nieuwe vaardigheden leren; zij kunnen het hun opvoeders echter ook lastiger maken, bijvoorbeeld door sterkere verbale vaardigheden (onderhandelen). In de literatuur wordt hogere intelligentie genoemd als een van de beschermende factoren bij het ontstaan van gedragsproblemen (Ten Brink \& Veerman, I998; Walsh, I998). De vraag is nu of intelligentere kinderen ook meer profiteren van een behandeling, in dit geval van STOP4-7. In overzichtsstudies van oudertrainingen wordt dit niet als modererende factor genoemd (zie o.a. Lundahl e.a., 2005).

Kinderen uit gezinnen met meervoudige problemen lijken minder te profiteren van 'evidence-based' behandelingen. Het zijn vooral de ouders met een veelheid aan problemen (Moran \& Ghate, 2005; Forehand \& Kotchik, 2002) die sneller afhaken in de behandeling en als ze volhouden minder sterke resultaten boeken. Het gaat vaak om alleenstaande moeders, met een beperkt sociaal netwerk en minder financiële mogelijkheden, die beperktere vooruitgang boeken en deze vooruitgang ook minder lang vasthouden (Assemany \& McIntosh, 2002; Serketich \& Dumas, I996). Lundahl e.a. (2005) geven in hun meta-analyse aan dat een lagere sociaal-economische status van het gezin en een eenoudergezin bij oudertrainingen zowel op het kindgedrag als op het opvoedkundig gedrag van ouders minder effecten te zien geven. Reyno en McGrath (2006) laten in hun meta-analyse zien dat eenoudergezinnen, grote gezinnen, een laag gezinsinkomen, psychische problemen bij de moeder en het meemaken van negatieve life-events en stressoren tot minder gunstige uitkomsten bij het kind leiden. 
Een aantal gezinnen in de trainingen is van Surinaamse, Marokkaanse of Turkse afkomst. Uit de literatuur blijkt dat gedragsproblemen bij kinderen van allochtone afkomst soms duidelijk in het teken staan van een moeilijk te overbruggen kloof tussen wat thuis en wat op school wordt verwacht (Kouratovsky, I996). De vraag is daarom of STOP4-7 voldoende aansluit bij deze groep. Mogelijk is de training voor deze groep minder effectief. Ook worden deze gezinnen vaak gekenmerkt door een veelheid aan problemen, zodat de in de vorige alinea genoemde verwachting van kleinere effecten ook hier van toepassing zijn.

In eerste instantie wordt voor STOP4-7 gedacht aan kinderen met de DSM-IV (hoofd)classificatie oppositionele gedragsstoornis (ODD). De vraag is of deze training ook werkt voor kinderen die een andere DSM-IV-classificatie hebben maar ook hardnekkige gedragsproblemen laten zien, zoals kinderen met pervasieve ontwikkelingsstoornissen (PDD), aandachtstekortstoornissen (ADHD) of reactieve hechtingsstoornissen (RAD). Hierover zijn geen gegevens in de literatuur gevonden.

De tweede vraagstelling kan op grond van het bovenstaande als volgt geformuleerd worden: welke kinderen en gezinnen hebben het meeste baat bij deze behandeling? Hebben kinderen met een gemiddelde en bovengemiddelde intelligentie meer baat bij de behandeling dan kinderen met een benedengemiddelde intelligentie? Hebben kinderen uit gezinnen met enkelvoudige gezinsproblemen meer baat bij de behandeling dan kinderen uit gezinnen met meervoudige gezinsproblemen? Hebben autochtone kinderen meer baat bij de behandeling dan allochtone kinderen? En hebben kinderen met de classificatie ODD meer baat bij de behandeling dan kinderen met PDD, ADHD of RAD?

\section{Methode}

\section{Design}

Het onderzoek is opgezet als een veranderingsonderzoek met een voor- en een nameting. Er is geen controlegroep; wel zijn de gegevens van de normgroepen van de verschillende meetinstrumenten gebruikt als referentie. Het design kent ook een follow-up na zes maanden, maar vanwege de te geringe respons zijn deze gegevens niet meegenomen in de huidige analyses.

\section{Onderzoeksgroep}

De aanvankelijke onderzoeksgroep bestond uit 69 van de in totaal 73 kinderen die in de periode april 2003 tot en met oktober 2005 bij Entréa en Trajectum aan de sTop4-7training begonnen. Vier kinderen stopten voortijdig met de behandeling (drie bij Entréa en één bij Trajectum). De kinderen van Entréa ( $N=3$ I) maakten al gebruik van jeugdzorg en bezochten de aan Entréa gelieerde school voor speciaal onderwijs voor kinderen met ernstige gedragsproblemen en/of psychiatrische problemen. De kinderen van Trajectum $(N=38)$ maakten alleen voor dit programma gebruik van jeugdzorg en bezochten overwegend het basisonderwijs en in mindere mate het speciaal basisonderwijs en het speciaal onderwijs. De leeftijd van de kinderen varieerde tussen vier en acht jaar $(M=5.8, S D=.87)$. 
Bij de kinderen moest sprake zijn van ernstige gedragsproblemen waar ouders onvoldoende vat op hadden. Het kind mocht niet elders in (psycho)therapie zijn, geen medicatie gebruiken, niet onder moeilijk lerend niveau functioneren en geen primaire taal-spraakstoornis hebben. Kinderen met een lichte autismespectrumstoornis, ADHD of een hechtingsstoornis werden niet per definitie uitgesloten van de training. Van belang hierbij was dat een kind in een groep kon functioneren en dat er geen alternatieve behandeling was die beter op de problematiek aansloot. Bij de ouders moest er sprake zijn van onvoldoende opvoedingsvaardigheden, van een ernstige mate van opvoedingsstress en een verstoorde gezagsrelatie tussen ouder en kind. Er mocht in principe geen sprake zijn van risicofactoren die de komst naar bijeenkomsten, het nakomen van afspraken en het in praktijk brengen van geleerde vaardigheden in de weg zouden staan. De leerkrachten moesten eveneens ernstige gedragsproblemen bij het kind hebben geconstateerd. Van hen werd verwacht dat zij gemotiveerd waren voor het volgen van de leerkrachttraining en zich als samenwerkingspartner van de behandelaars zouden opstellen.

Niet van alle kinderen konden voor- en nametingen met de onderzoeksinstrumenten verkregen worden. De respons op de onderzoeksinstrumenten (afname van voor- en nameting) varieerde van $65-74 \%$, waardoor de aantallen voor de analyses variëren van 44-5I (dit staat in tabel I per instrument aangegeven).

Voorafgaande aan de beantwoording van de vraagstellingen is gekeken of er verschillen waren tussen de groep waarvan de gegevens in de analyses worden gebruikt (de responders; criterium: voor- en nametingen aanwezig) en de groep die buiten de analyses blijft omdat er geen voor- of nameting verkregen kon worden (de non-responders). Nagegaan werd of er verschillen tussen de responders en non-responders zijn wat betreft leeftijd en geslacht en op de voormetingen van alle schalen die ook voor de analyses van de veranderingen zijn gebruikt (zie tabel I voor een overzicht van deze schalen). Voor Leeftijd ( $t(67)=-.6 \mathrm{I}, p=.55)$ en Geslacht (Fisher's Exact test, $p=$ I.००) werden geen verschillen gevonden tussen responders en non-responders. Wat betreft de voormetingen werden er in achttien analyses drie verschillen gevonden. Non-responders hadden volgens de leerkrachten bij aanvang minder internaliserende problemen dan responders, en de ouders van non-responders gaven aan meer regels te stellen en meer sociaal te belonen dan de ouders van responders $(p<.05)$.

\section{Meetinstrumenten}

- Child Behavior Checklist ( $C B C L$ ). De CBCL is een genormeerde vragenlijst om ouders de gedragsproblemen en sociale competentie van hun kinderen te laten beoordelen. Via de СвСL wordt zowel internaliserend (naar binnen gericht, teruggetrokken) probleemgedrag, als externaliserend (naar buiten gericht, agressief) probleemgedrag geïnventariseerd. De van oorsprong Amerikaanse lijst van Achenbach is door Verhulst e.a. voor het Nederlandse taalgebied toegankelijk gemaakt (Verhulst, Van der Ende \& Koot, I996). De свсL wordt nationaal en internationaal in veel onderzoek als meetinstrument gehanteerd en kent goede psychometrische eigenschappen (zie de cotan-beoordeling; Evers, Van Vliet-Mulder \& Groot, 200I). In dit onderzoek wordt de schaal Externaliseren (33 items) gebruikt als operationalisatie van 
ernstig probleemgedrag en wordt als contrast in de analyses ook de schaal Internaliseren (3I items) meegenomen.

- Teacher's Report Form (TRF). De TRF is de leerkrachtversie van de CBCL. Het betreft hier de genormeerde Nederlandse versie waarmee leerkrachten gedragsproblemen en adaptief functioneren van leerlingen kunnen beoordelen. Ook met de TRF wordt zowel internaliserend (35 items) als externaliserend probleemgedrag (34 items) geïnventariseerd (Verhulst, Van der Ende \& Koot, I997). De TRF wordt, net als de СвСL, nationaal en internationaal in veel onderzoek als meetinstrument gehanteerd en kent goede psychometrische eigenschappen (COTAN; Evers e.a., 200I).

- Strengths and Difficulties Questionnaire (SDQ). De SDQ is een korte, oorspronkelijk door Goodman ontwikkelde, vragenlijst (25 items) die de aanwezigheid van gedragsproblemen bij jeugdigen en de gevolgen daarvan voor het dagelijks functioneren vaststelt, en die tevens de sterke kanten van de jeugdigen belicht. Er zijn drie vrijwel identieke versies van de SDQ, namelijk een versie voor ouders, leerkrachten, en één voor jongeren van II-I8 jaar. Deze zijn alle voor het Nederlands taalgebied beschikbaar (Goedhart, Treffers \& Van Widenfelt, 2003). De lijst kent vijf subschalen met elk vijf vragen: Emotionele problemen, Gedragsproblemen, Hyperactiviteit, Problemen met leeftijdgenoten en Prosociaal gedrag. Alleen deze laatste schaal, die met name het inlevingsvermogen van kinderen meet, wordt in de analyses gebruikt. De betrouwbaarheid en validiteit worden door de cotan als voldoende beoordeeld (Nederlands Instituut van Psychologen, 2007).

- Nijmeegse Ouderlijke Stress Index (NOSI) .Via de Nosi wordt de opvoedingsbelasting van ouders gemeten. Deze opvoedingsbelasting wordt gesitueerd in aspecten die op het kind betrekking hebben (zoals veeleisend gedrag, afleidbaarheid, stemming) en aspecten die aan de ouders zelf worden toegeschreven (zoals depressie, sociale isolatie, relatieproblemen). De nosi is gebaseerd op de Amerikaanse Parenting Stress Index van Abidin, die begin jaren negentig van de vorige eeuw voor het Nederlandse taalgebied is aangepast en onderzocht door De Brock, Vermulst, Gerris en Abidin (I992). In het hier gerapporteerde onderzoek werd gebruik gemaakt van de vernieuwde versie en de voorlopige normen uit 2004 (De Brock, Vermulst, Gerris, Veerman \& Abidin, 2004). Betrouwbaarheid en validiteit van de vorige Nederlandse versie waren voldoende tot goed (COTAN; Evers e.a., 200I). In de analyses worden de schalen Competentie (7 items), Rolrestrictie ( 6 items), Hechting (5 items) uit het ouderdomein gebruikt, en de schalen Stemming (6 items), Veeleisendheid ( 6 items), Positieve bekrachtiging ( 5 items) en Acceptatie (7 items) uit het kinddomein. Op de andere schalen werd op korte termijn geen verbetering verwacht, dit zijn de schalen Depressie, Gezondheidsbeleving, Sociale isolatie en Huwelijksrelatie uit het ouderdomein, en de schalen Aanpassing en Afleidbaarheid uit het kinddomein.

- Schaal voor Ouderlijk Gedrag (SOG). De soG4-7 is ontwikkeld door Van Leeuwen (I999). Dit instrument is gebaseerd op de theorie van Patterson. De oorspronkelijke SOG is voor kinderen van 8-I4 jaar en aangepast voor en genormeerd bij kinderen van 4-7 jaar (Van Leeuwen, 2002; Logie, 2005). Bij deze leeftijdsgroep werden na factoranalyse acht schalen geconstrueerd, waarvan er vijf in het huidige onderzoek werden gebruikt: Positief ouderlijk gedrag (7 items), Stellen van regels (6 items), 
Hard straffen ( 3 items), Inconsequent straffen ( 3 items) en Sociaal belonen ( 2 items). De overige drie schalen Straffen, Negeren en Materieel belonen zijn in dit onderzoek niet meegenomen, evenals zes items die niet tot een schaal behoren, omdat de vragen bij de ouders verwarring oproepen, aangezien ze niet meten wat de ouders in de oudertraining leren.

- Overige gegevens. Voor het beantwoorden van de tweede onderzoeksvraag zijn gegevens verzameld over intelligentie, etniciteit, type probleemgezin en het diagnostisch beeld van het kind. Gedragswetenschappers van beide instellingen leverden deze gegevens aan. Wat betreft de intelligentie zijn, voor zover bekend, uitslagen op intelligentietesten genomen. Hierbij werd een totale IQ-score $<90$ als beneden gemiddeld geclassificeerd, een score van 9o-IIo als gemiddeld en een score > IIo als boven gemiddeld geclassificeerd. Als er geen intelligentietest voorhanden was, is uitgegaan van het klinische oordeel van de gedragswetenschapper over het betreffende kind. Type probleemgezin werd eveneens door de gedragswetenschapper beoordeeld (als enkelvoudige versus meervoudige gezinsproblemen). Etniciteit werd gecodeerd op basis van het geboorteland van de ouders. Wat betreft het diagnostisch beeld is uitgegaan van de DSM-IV-classificatie zoals gesteld door de kinderpsychiater of Gz-psycholoog/gedragswetenschapper.

\section{Procedures}

Bij aanvang en einde van de behandeling zijn de vragenlijsten aan de ouders meegegeven of toegestuurd. De coördinator van het project op de instelling droeg er zorg voor dat de lijsten (via pedagogisch medewerkers, maatschappelijk werk of per post) bij de onderzoeker terechtkwamen.

\section{Statistische analyses}

$\mathrm{Bij}$ het interpreteren van de onderzoeksgegevens is gebruik gemaakt van deviatiescores. Deze worden voor genormeerde vragenlijsten berekend door het verschil tussen de individuele ruwe score en het gemiddelde van de normgroep te delen door de standaarddeviatie van de normgroep. Dit geeft een gestandaardiseerde score ( $z$-score) voor de afwijking van de norm. Hierbij geldt: hoe groter de afwijking van de norm (eenzijdig), des te ernstiger de problemen. Voor de interpretatie van deze scores werd een deviatiescore van I.282 in dit onderzoek als benedengrens van het klinische gebied gehanteerd (90\% van de normgroep scoort lager).

Om inzicht te krijgen in eventuele behandeleffecten zijn ook effectgrootten berekend (ES). Deze zijn berekend door de score op de nameting af te trekken van de score op de voormeting en dit verschil te delen door de 'gepoolde' standaarddeviatie van de voor- en nameting. De Es geeft dan aan hoeveel eenheden van een standaarddeviatie een cliënt na de behandeling verbeterd dan wel verslechterd is. Een positieve Es duidt op een positief effect, een negatieve Es duidt op een negatief effect. Een ES $<.20$ is niet noemenswaardig, een Es van .20-.49 wordt klein genoemd, van .50-.79 is de Es middelgroot en $\mathrm{bij} \geq .80$ is er sprake van een grote Es (Cohen, I988).

Om de eerste onderzoeksvraag naar de effectiviteit van STOP4-7 te beantwoorden zijn $t$-toetsen voor afhankelijke groepen uitgevoerd. Voor het beantwoorden van de tweede onderzoeksvraag (welke kinderen hebben baat bij het programma) zijn MANovA's met 
herhaalde metingen uitgevoerd, met relevante prognostische factoren als onafhanke-

lijke variabelen en de verandering in externaliserend gedrag als afhankelijke variabele. Intelligentie is ingedeeld in drie niveaus: benedengemiddeld, gemiddeld en bovengemiddeld. Deze indeling is gebaseerd op klinische oordelen. Van negentien cases bleken ook IQ-scores beschikbaar. Ook met deze subgroep is het verband tussen IQ en Externaliseren getoetst. De aantallen per groep om het verband tussen IQ en ouderbeoordelingen van Externaliseren $(n=\mathrm{I} 7)$ te toetsen waren 5 (benedengemiddeld $\mathrm{IQ}$ ), 7 (gemiddeld IQ) en 5 (bovengemiddeld IQ), de aantallen per groep om het verband tussen IQ en leerkrachtbeoordelingen van Externaliseren $(n=\mathrm{I} 9)$ te toetsen waren respectievelijk 7, 7 en 5. De overige factoren zijn als volgt ingedeeld: Type probleemgezin (twee groepen: enkelvoudige gezinsproblemen vs. meervoudige gezinsproblemen); Etniciteit (twee groepen: allochtoon vs. autochtoon); Diagnostisch beeld (DSM-IV classificatie ODD, ADHD, PDD of RAD). Om significante verschillen bij prognostische factoren met meer dan twee niveaus/groepen nader te specificeren, zijn post-hoctoetsen uitgevoerd met een gecomponeerde verschilscore tussen voor- en nameting op Externaliseren als afhankelijke variabele. Bij gelijke varianties (homogeniteit) tussen groepen is gekozen voor de Bonferroni-post-hoctest, bij ongelijke varianties tussen groepen is met Dunnetts $\mathrm{T}_{3}$ gecontroleerd.

\section{Resultaten}

In tabel I staan de uitkomsten op de vraag of sTo 4-7 effectief is. Uit de tabel blijkt dat dertien van de achttien uitgevoerde $t$-toetsen significant zijn. Uit de effectgrootten blijkt dat de grootste veranderingen worden waargenomen in het opvoedingsgedrag van de ouders. Zij zijn vooral consequenter gaan straffen $(\mathrm{ES}=.76)$, ook straffen ze minder hard $(\mathrm{ES}=.30)$. De gemiddelde deviatiescores op de sog waren echter bij de voormeting al lager dan I.282, wat betekent dat de ouders het eigen opvoedingsgedrag bij aanvang als niet al te problematisch beoordeelden.

Bij Externaliseren op de СвСL komt naar voren dat er weliswaar sprake is van een verbetering $(\mathrm{ES}=.45)$, maar dat de kinderen gemiddeld genomen na de training nog steeds een score hebben die op 'ernstige problemen' duidt. Internaliserend gedrag (СвCL) en Prosociaal gedrag (SDQ) is volgens de ouders ook licht verbeterd (Es resp. .33 en .43), maar hier liggen de gemiddelde scores na de behandeling niet meer in het probleemgebied. Op zes van de zeven Nosi-schalen is er een verbetering aantoonbaar. Ten aanzien van Stemming bij het kind is deze het grootst $(\mathrm{ES}=.45)$. Ook hier geldt dat de score voor de behandeling gemiddeld nog in het probleemgebied lag en na de behandeling niet meer. De leerkrachten rapporteren geen verbetering voor Externaliseren, maar wel voor Internaliseren $(\mathrm{ES}=.35)$ en Prosociaal gedrag $(\mathrm{ES}=.34)$.

Het aantal kinderen dat na afloop van de behandeling nog zorgwekkende problemen vertoont, varieert van $27 \%$ (Internaliseren beoordeeld door leerkrachten) tot 60\% (Externaliseren beoordeeld door ouders). Wat betreft het opvoedingsgedrag scoort Io$23 \%$ van de ouders in het probleemgebied, wat betreft de ervaren opvoedingsbelasting $27-64 \%$.

Welke kinderen en gezinnen hebben het meeste baat bij sTop4-7? De MANova laat 
Tabel 1 Verandering in problemen volgens ouders en leerkrachten.

\begin{tabular}{|c|c|c|c|c|c|c|c|c|c|}
\hline \multirow[t]{2}{*}{ Dimensie } & \multirow[t]{2}{*}{$\alpha$} & \multirow[t]{2}{*}{$N$} & \multicolumn{2}{|c|}{ Voormeting } & \multicolumn{2}{|c|}{ Nameting } & \multirow[t]{2}{*}{$t$} & \multirow[t]{2}{*}{$\begin{array}{l}\text { Effect- } \\
\text { grootte }\end{array}$} & \multirow[t]{2}{*}{$\%$ PG } \\
\hline & & & $M$ & $S D$ & $M$ & $S D$ & & & \\
\hline \multicolumn{10}{|l|}{ Ouders } \\
\hline \multicolumn{10}{|l|}{$\mathrm{CBCL}$} \\
\hline $\begin{array}{l}\text { - Externaliserend } \\
\text { gedrag }\end{array}$ & .87 & 48 & 2.50 & 1.45 & 1.84 & 1.50 & $3.70^{* *}$ & .45 & $60 \%$ \\
\hline $\begin{array}{l}\text { - Internaliserend } \\
\text { gedrag }\end{array}$ & .86 & 48 & 1.62 & 1.77 & 1.06 & 1.67 & $3.011^{* *}$ & .33 & $31 \%$ \\
\hline \multicolumn{10}{|l|}{ SDO } \\
\hline - Prosociaal gedrag ${ }^{\dagger}$ & .65 & 51 & 1.55 & 1.36 & .99 & 1.23 & $3.61^{* *}$ & .43 & $35 \%$ \\
\hline \multicolumn{10}{|l|}{ soG } \\
\hline $\begin{array}{l}\text { - Positief ouderlijk } \\
\text { gedrag }^{\dagger}\end{array}$ & .78 & 45 & .23 & 1.23 & .16 & 1.12 & .47 & .06 & $16 \%$ \\
\hline - Stellen van regels ${ }^{\dagger}$ & .84 & 45 & .53 & 1.39 & .38 & 1.15 & .89 & .11 & $22 \%$ \\
\hline - Hard straffen & .74 & 45 & .33 & 1.23 & -.02 & 1.12 & $2.57^{*}$ & .30 & $18 \%$ \\
\hline $\begin{array}{l}\text { - Inconsequent } \\
\text { straffen }\end{array}$ & .50 & 45 & .69 & .93 & -.07 & 1.07 & $4.06^{* *}$ & .76 & $16 \%$ \\
\hline - Sociaal belonen ${ }^{\dagger}$ & .56 & 44 & .20 & 1.01 & .10 & 1.08 & .54 & .09 & $23 \%$ \\
\hline \multicolumn{10}{|l|}{ NOSI } \\
\hline - Competentie & .89 & 47 & .86 & 1.47 & .51 & 1.41 & $2.86^{* *}$ & .25 & $34 \%$ \\
\hline - Rolrestrictie & .83 & 45 & .93 & 1.59 & .57 & 1.74 & $2.05^{*}$ & .22 & $42 \%$ \\
\hline - Hechting & .71 & 45 & .68 & 1.52 & .31 & 1.34 & $2.17^{*}$ & .26 & $27 \%$ \\
\hline - Stemming & .83 & 47 & 1.84 & 1.31 & 1.22 & 1.44 & $4.21^{* *}$ & .45 & $51 \%$ \\
\hline - Veeleisendheid & .85 & 47 & 1.78 & 1.27 & 1.40 & 1.57 & $2.66^{*}$ & .27 & $62 \%$ \\
\hline $\begin{array}{l}\text { - Positieve } \\
\text { bekrachtiging }\end{array}$ & .69 & 47 & .63 & 1.26 & .47 & 1.24 & 1.09 & .13 & $34 \%$ \\
\hline - Acceptatie & .74 & 45 & 1.75 & 1.56 & 1.31 & 1.56 & $2.72^{* *}$ & .29 & $64 \%$ \\
\hline \multicolumn{10}{|l|}{ Leerkrachten } \\
\hline \multicolumn{10}{|l|}{ TRF } \\
\hline $\begin{array}{l}\text { - Externaliserend } \\
\text { gedrag }\end{array}$ & .96 & 48 & 2.28 & 2.28 & 1.99 & 1.83 & 1.34 & .14 & $63 \%$ \\
\hline $\begin{array}{l}\text { - Internaliserend } \\
\text { gedrag }\end{array}$ & .82 & 48 & 1.08 & 1.19 & .69 & 1.03 & $3.29^{* *}$ & .35 & $27 \%$ \\
\hline \multicolumn{10}{|l|}{ SDO } \\
\hline - Prosociaal gedrag ${ }^{\dagger}$ & .80 & 49 & 1.86 & 1.16 & 1.44 & 1.34 & $2.86^{* *}$ & .34 & $65 \%$ \\
\hline
\end{tabular}

De coëfficiënt voor interne consistentie $(\alpha)$ is berekend op basis van de scores op de voormeting van de huidige onderzoeksgroep. \%PG is het percentage kinderen dat bij afsluiting nog in het probleemgebied scoort (deviatiescore $\geq 1.282$ ). " $p<.05 ; " p<$ <.01. De positief gescoorde schalen (aangeduid met ${ }^{\dagger}$ ) zijn in de analyses gespiegeld, zodat de richting van de betekenis ervan overeenstemt met de scores op de overige schalen (hoe hoger de score, des te meer problemen). 


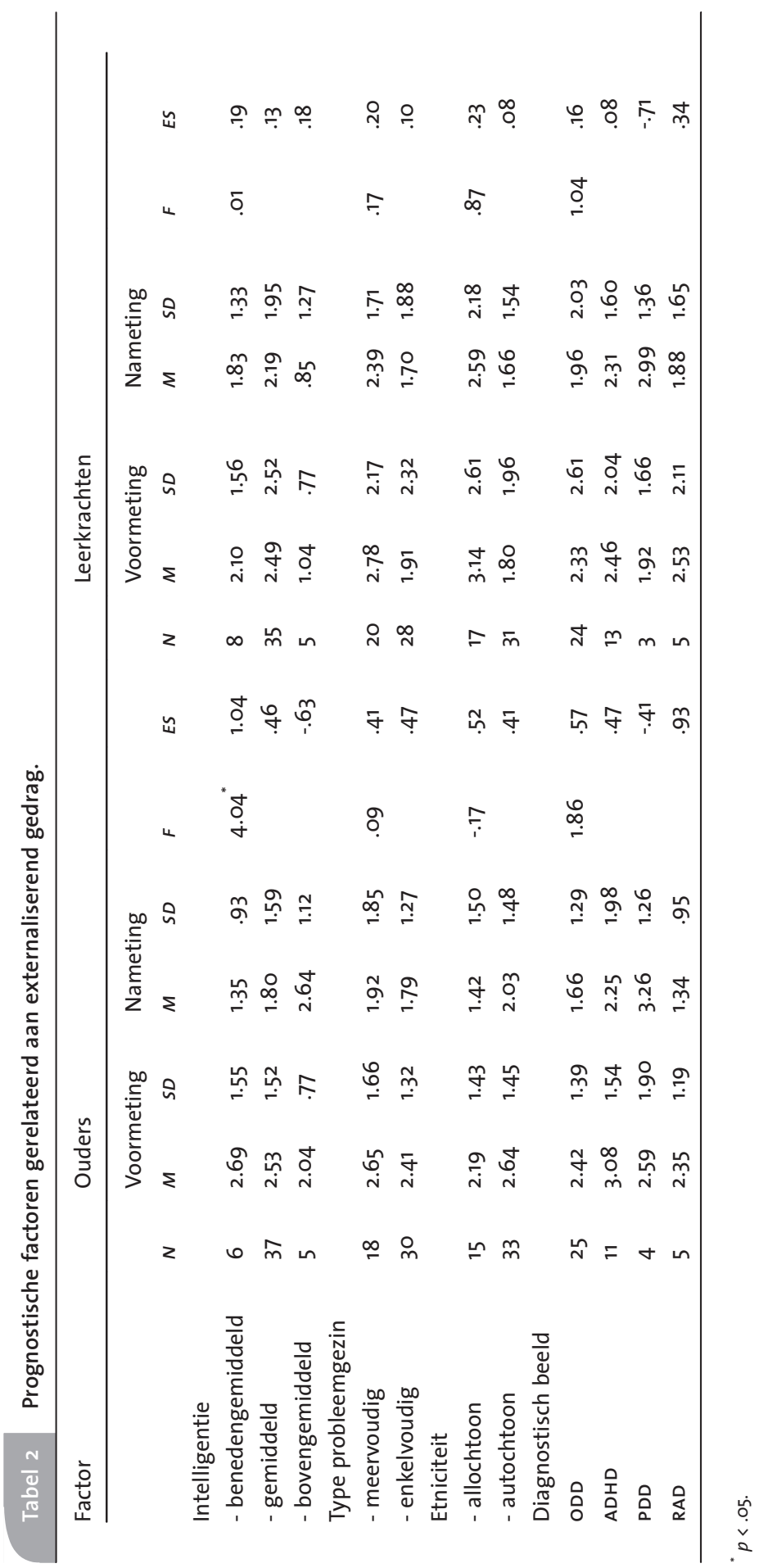


wat betreft het externaliserend gedrag beoordeeld door de ouders een significant verschil zien voor Intelligentie $(F(2,45)=4.04, p=.02)$. Uit de post-hoctest bleek dat volgens ouders kinderen met een bovengemiddelde intelligentie significant minder hebben geprofiteerd van de behandeling dan kinderen met een benedengemiddelde intelligentie. Kinderen met een bovengemiddelde intelligentie vertoonden na de training zelfs meer externaliserend probleemgedrag ( $\mathrm{ES}=-.63)$. Wat betreft de leerkrachtoordelen is hier geen significant verschil gevonden $(F(2,45)=.0 \mathrm{I}, p=.99)$. Aangezien de beoordeling van intelligentie voor het merendeel op klinische oordelen gebaseerd is, kan dit mogelijk de resultaten beïnvloed hebben en moeten de hier gerapporteerde resultaten dan ook met grote voorzichtigheid geïnterpreteerd worden.

Voor een klein deel van de onderzoeksgroep is de indeling echter gebaseerd op scores op intelligentietesten. Statistische analyses op deze subgroep ( $n=$ I7 voor ouders, $n=$ I9 voor leerkrachten) leidde tot min of meer vergelijkbare uitkomsten: nagenoeg significante verschillen bij ouderbeoordelingen van probleemgedrag $(F(2, \mathrm{I} 4)$ $=3.70, p=.05 \mathrm{I})$ en geen significante verschillen bij leerkrachtbeoordelingen $(F(2, \mathrm{I} 6)=$ $2.09, p=.156)$. Afgaande op de ouderbeoordelingen hebben kinderen met een bovengemiddelde IQ-score minder geprofiteerd van de behandeling $(\mathrm{ES}=-.86)$ vergeleken met kinderen met een gemiddelde IQ-score $(\mathrm{ES}=.53)$ en kinderen met een benedengemiddelde intelligentie ( $\mathrm{ES}=.7 \mathrm{I})$.

Voor de overige prognostische factoren (type probleemgezin, etniciteit en diagnostisch beeld) zijn er geen significante verschillen gevonden wat betreft afname van externaliserend gedrag beoordeeld door zowel ouders als leerkrachten. Met betrekking tot diagnostisch beeld is voor een aantal afzonderlijke stoornissen wel een trend waar te nemen die van betekenis kan zijn voor de indicatiestelling voor het sTOP4-7-programma. Deze uitkomsten moeten echter met grote voorzichtigheid worden geïnterpreteerd, want de analyse werd met zeer kleine aantallen gedaan. Zo is uit tabel 2 af te lezen dat kinderen met RAD na de training een grote verbetering laten zien wat betreft externaliserend gedrag ( $\mathrm{ES}=.95)$. Ter vergelijking, de doelgroep (kinderen met ODD) laat hierop een middelgrote vooruitgang zien. Kinderen met PDD daarentegen laten zowel volgens de ouders $(\mathrm{ES}=-.4 \mathrm{I})$ als de leerkrachten $(\mathrm{ES}=-.7 \mathrm{I})$ een verslechtering zien. Ten slotte wordt bij kinderen met ADHD een lichte vooruitgang geconstateerd op externaliserend gedrag beoordeeld door de ouders ( $\mathrm{ES}=.47)$. De leerkrachten van deze ADHD-kinderen signaleren daarentegen geen verbetering op externaliserend gedrag (ES $=.08)$.

\section{Discussie}

Uit dit onderzoek komt naar voren dat kinderen en ouders die het sтор4-7-programma gevolgd hebben, positieve veranderingen laten zien. De kinderen vertonen na de behandeling volgens de ouders minder externaliserend en internaliserend gedrag en meer prosociaal gedrag. Echter, bij de nameting is het externaliserende gedrag bij verschillende kinderen nog steeds problematisch $160 \%$ scoort in het probleemgebied van de СвСL). Het prosociale gedrag en het internaliserende gedrag van het kind vallen bij nameting gemiddeld genomen wel buiten het probleemgebied. De leerkrachten 
zien geen verbetering op externaliserend gedrag, maar wel op internaliserend en prosociaal gedrag. De ouders zijn naar eigen zeggen beter gaan opvoeden, al ervoeren ze hun eigen opvoedingsgedrag bij aanvang van de behandeling al niet als erg problematisch. De grootste verandering in opvoedingsgedrag zit in het meer consequent straffen door de ouders. De ervaren opvoedingsbelasting van de ouders is ook significant gedaald, maar ook hier scoort $27-64 \%$ van de ouders nog in het probleemgebied. De stemming van het kind veranderde volgens de ouders nog het meest.

De gevonden effecten zijn voor het merendeel klein tot middelgroot (ES .20-.50). Lundahl e.a. (2005) vonden in hun meta-analyse van op gedragstherapeutische leest geschoeide oudertrainingen een gemiddelde Es van .42 voor gedragsveranderingen bij kinderen, .45 voor gedragsveranderingen bij ouders en .53 voor veranderingen in ouderlijke percepties. Onze resultaten zijn daarmee in overeenstemming. In Vlaanderen evalueert De Mey (persoonlijke communicatie, 2006) eveneens sтop4-7. De eerste resultaten laten zien dat de (voorlopige) Es wat betreft externaliserend gedrag (ouders) .56 is. Iets groter dus dan in dit onderzoek $(\mathrm{ES}=.45)$. De effectgrootte van het oordeel van de leerkracht is in het Vlaamse onderzoek .33 (bij ons ES =.I4); de ouders zijn net als in dit onderzoek consequenter gaan opvoeden ( $\mathrm{ES}=.64$; bij ons Es $=.76$ ).

Ondanks de aangetoonde veranderingen kan het huidige onderzoek geen definitieve uitspraken doen over de werkzaamheid van STOP4-7. Zijn de gevonden effecten door dit programma veroorzaakt of zijn er alternatieve verklaringen denkbaar? Mogelijk groeien kinderen over hun problemen heen (rijping of spontaal herstel) of hebben gunstige veranderingen in hun omgeving (een andere school, een verhuizing) een positieve invloed. Bovendien kunnen hoge scores bij aanvang wellicht niet anders dan tot lagere scores bij afsluiting leiden (statistische regressie naar het gemiddelde). Het inschakelen van een controlegroep zou hierover meer uitsluitsel kunnen geven. Wel is de interventie in theorie effectief, door de duidelijke opbouw van de interventie, het aanwezig zijn van protocollen en de theoretische onderbouwing. Tezamen met de geconstateerde veranderingen vormen dit indicaties dat de bewijskracht voor de effectiviteit van STOP4-7 zich op het derde van de vier niveaus van effectiviteit op de effectladder bevindt (Veerman \& Van Yperen, 2007). Een goede beschrijving en theoretische onderbouwing van een interventie vormen op deze ladder de eerste twee niveaus, een vergelijking met een controlegroep is kenmerkend voor het vierde niveau.

De uitkomsten met betrekking tot de factoren Intelligentie en Diagnostisch beeld moeten met grote voorzichtigheid worden geïnterpreteerd omdat de analyses op kleine aantallen zijn gedaan; de bespreking hiervan is nadrukkelijk hypothesegenererend. Toch is het opvallend dat, vergeleken met kinderen met een benedengemiddelde en gemiddelde intelligentie, bij kinderen met een bovengemiddelde intelligentie het externaliserende probleemgedrag toenam. De groepjes kinderen met een beneden- en bovengemiddelde intelligentie zijn klein. Een mogelijke verklaring is dat de meer intelligente kinderen best weten hoe het hoort maar bewust de regels overschrijden en willen onderhandelen, en dat de minder intelligente kinderen voor de training nog niet goed wisten wat volwassenen van hen verwachtten. Een goede intelligentie is weliswaar een protectieve factor bij het ontstaan van gedragsproblemen (Ten Brink \& Veerman, I998; Walsh, I998), maar misschien niet bij het opheffen ervan. Het lijkt zinvol om in 
vervolgonderzoek dit aspect opnieuw mee te nemen, zodat een uitspraak gedaan kan worden die gebaseerd is op grotere aantallen.

Opvallend is ook de (overigens niet-significante) tendens dat kinderen met hechtingsstoornissen volgens de ouders het meest van de training profiteerden, en dat kinderen met PDD volgens ouders en leerkrachten zelfs achteruitgingen. De veronderstelling op basis van bovenstaande bevindingen is dat de training geschikt is voor zowel kinderen met de hoofdclassificatie oDD, als voor kinderen met de hoofdclassificatie ADHD en voor kinderen met hechtingsstoornissen, maar dat de training voor kinderen met PDD aanpassingen behoeft omdat zij minder goed leren van modelling en meer uitleg nodig hebben over oorzaak-gevolgrelaties. Het voert voor dit artikel te ver om te speculeren over de vraag waarom kinderen met hechtingsstoornissen van de training profiteren. Wel willen we hier aangeven dat aan probleemgedrag vaak een hechtingsstoornis of ouder-kindrelatieproblematiek ten grondslag ligt en dat in deze training veel aspecten zitten die een positieve ouder-kindrelatie bevorderen.

De bevinding dat zowel ouders als leerkrachten aangeven dat internaliserend gedrag afneemt en prosociaal gedrag toeneemt, en dat beide niet langer problematisch zijn, is eveneens opvallend. Mogelijk treedt het verbeteren van deze gedragsaspecten als een buffer op voor de consequenties van het (nog steeds problematische) externaliserende gedrag. Met andere woorden, deze kinderen hebben ondanks hun problemen betere relaties met hun leeftijdgenoten gekregen en zijn minder angstig in het contact. Dit zou de prognose voor het verder afnemen van het externaliserend gedrag juist voor deze kinderen gunstig kunnen laten zijn (Dodge e.a., 2003). Follow-up-onderzoek kan dit wellicht bevestigen.

Tot slot een tweetal aanbevelingen voor vervolgonderzoek. Ten eerste zou, zoals eerder aangegeven, in de onderzoeksopzet ook een controlegroep moeten worden opgenomen. Hiermee kan er meer bewijskracht komen dat de gunstige veranderingen te danken zijn aan de sтоP4-7-training. Ten tweede was de respons op de vragenlijsten wat betreft de voor- en nametingen redelijk maar voor de follow-up laag. Deze gegevens zijn daarom niet in dit artikel besproken. Het is belangrijk deze gegevens wel te verzamelen, aangezien theoretisch verwacht kan worden dat de nieuwe opvoedkundige vaardigheden van ouders tijd nodig hebben om goed in te werken op het gedrag van het kind. Mogelijk kan deze gegevensverzameling gecombineerd worden met een opfriscursus of terugkombijeenkomst voor de ouders.

\section{Literatuur}

Nederlands Instituut van Psychologen (2007). Documentatie van tests en testresearch in Nederland. Aanvulling 2007/02. Amsterdam. Nip/Boom.

Assemany, A. E., \& McIntosh, D. E. (2002). Negative treatment outcomes of behavioral parent training programs. Psychology in the Schools, 39, 209-219.

Brestan, E. V., \& Eyberg, S. M. (I998). Effective psychosocial treatments of conduct-disordered children and adolescents: 29 years, 82 studies, and 5,272 kids. Journal of Clinical Child Psychology, 27, 180-189.

Campbell, S. B. (1995). Behavior problems in preschool children: A review of recent research. Journal of Child Psychology and Psychiatry, 36, II3-I49. 
Cohen, J. (1988). Statistical power analysis for the behavioral sciences (2nd Ed.). Hillsdale, NJ: Lawrence Erlbaum.

De Brock, A. J. L. L., Vermulst, A. A., Gerris, J. R. M., \& Abidin, R. R. (I992). NOsI. Nijmeegse Ouderlijke Stress Index. Handleiding experimentele versie. Lisse: Swets \& Zeitlinger.

De Brock, A. J. L. L., Vermulst, A. A., Gerris, J. R. M., Veerman, J. W., \& Abidin, R. R. (2004). Nijmeegse Ouderlijke Stress Index-R. Voorlopige handleiding. Nijmegen: Behavioural Science Institute.

De Mey, W. (2000). Het LIFT-project: Een eerste aanzet tot een preventieproject dat school en gezin verbindt. In W. De Mey, E. Moens, K. Van Leeuwen \& L.Verhofstadt-Denève (Red.), Preventie van antisociaal gedrag: starten bij de (pre)conceptie? (pp. I89-I99). Gent: Vyncke.

De Mey, W. (2005). Samen Sterker Terug Op Pad: STOP. Een vroegtijdige interventie voor jonge kinderen met gedragsproblemen. Amsterdam: swp.

Delicat, J. W. (2003). Vroeg, intensief en multimodaal. Vroegtijdige preventie voor 4-7 jarige 'opstandige' kinderen: een literatuuronderzoek. Nijmegen: Praktikon/ Radboud Universiteit.

Dishion, T. J., French, D. C., \& Patterson, G. R. (I995). The development and ecology of antisocial behavior. In D. Cicchetti \& D.J. Cohen (Eds.), Developmental psychopathology, Vol. 1. Theory and methods (pp. 42I-47I). New York: John Wiley \& Sons.

Dodge, K. A., Lansford, J. E., Burks, V. S., Bates, J. E., Pettit, G. S., Fontaine, R., et al. (2003). Peer rejection and social information processing factors in the development of aggressive behavior and problems in children. Child Development, 74, 374-393.

Eddy, J.M., Reid, J.B., \& Fetrow, R.A. (2000). An elementary school-based prevention program targeting modifiable antecedents of youth delinquency and violence: Linking the Interests of Families and Teachers (LIFT). Journal of Emotional and Behavioral Disorders, 8, I65-176.

Evers, A., Vliet-Mulder, van, J. C., \& Groot, C. J. (200I). Documentatie van tests en testresearch in Nederland. Assen: Van Gorcum.

Forehand, R., \& Kotchik, B. A. (2002). Behavioral parent training: current challenges and potential solutions. Journal of Child and Family Studies, 11, 377-384.

Goedhart, A., Treffers, F., \& Van Widenfelt, B. (2003). Vragen naar psychische problemen bij kinderen. De Strengths and Difficulties Questionnaire (SDQ). Maandblad Geestelijke Volksgezondheid, 58 , I0I8-1035.

Kazdin, A. E., \& Weisz, J. R. (I998). Identifying and developing empirically supported child and adolescent treatments. Journal of Consulting and Clinical Psychology, 66, I9-36.

Kouratovsky, V. (I996). Transculturele psychiatrie en psychotherapie. Handboek voor hulpverleners en beleid. Lisse: Swets \& Zeitlinger.

Loeber, R., Slot, N. W., \& Sergeant, J. A. (Red.). (200I). Ernstige en gewelddadige jeugddelinquentie. Omvang, oorzaken en interventies. Houten/Diegem: Bohn Stafleu van Loghum.

Logie, H. (2005). Evaluatie van de Schaal voor Ouderlijk Gedrag, versie ouders van kinderen tussen 4 en 7 jaar. (Scriptie tot het behalen van de graad licentiaat in de psychologie). Gent: Universiteit Gent.

Lundahl, B., Risser, H. J., \& Lovejoy, M. C. (2005). A meta-analysis of parent training. Moderators and followup effects. Clinical Psychology Review, 26, 86-104.

Moran, P., \& Ghate, D. (2005). The effectiviness of parenting support. Children and Society, 19, 329-336.

Orobio de Castro, B., Veerman, J. W., Koops, W., Bosch, J. D., \& Monshouwer, H. J. (2002). Hostile attribution of intent and aggressive behaviour: A meta-analysis. Child Development, 73, 916-934.

Patterson, G. R. (I982). Coercive family process. Eugene, or: Castalia.

Patterson, G. R. (2002). The early development of coercive process. In J. B. Reid, G. R. Patterson \& J. Snyder (Eds.), Antisocial behaviour in children and adolescents. A developmental analysis and model for intervention (pp. 25-44). Washington, DC: American Psychological Association.

Patterson, G. R., Reid, J. B., \& Dishion, J.B. (I992). Antisocial boys. Eugene, or: Castalia. 
Reid, J. B., Patterson G. R., \& Snyder, J. (2002). Antisocial behavior in children and adolescents. A developmental analysis and model for intervention. Washington, DC: American Psychological Association.

Reyno, S. M., \& McGrath, P. J. (2006). Predictors of parent training efficacy for child externalizing problems. A meta-analytic review. Journal of Child Psychology and Psychiatry, 47, 99-III.

Scott, S., Knapp, M., Henderson, J., \& Maughan, B. (200I). Financial cost of social exclusion: Follow up study of antisocial children into adulthood. British Medical Journal, 323, I-5.

Serketich, W. J., \& Dumas, J. E. (I996). The effectiveness of behavioral parent training to modify antisocial behavior in children: A meta-analysis. Behavior Therapy, 27, I7I-I86.

Ten Brink, L. T., \& Veerman, J. W. (I998). Risicofactoren en protectieve factoren in de ontwikkeling van kinderen en adolescenten. In J.D. Bosch, H. A. Bosma, R. J. van der Gaag, A. J. J. M. Ruijssenaars \& A. Vyt (red.), Jaarboek ontwikkelingspsychologie, orthopedagogiek en kinderpsychiatrie (pp. 13-46). Houten: Bohn Stafleu van Loghum.

Van de Wiel, N. (2002). The effect of manualized behavior therapie with disruptive behavior disordered children in everyday clinical practice: A randomized clinical trial. (Proefschrift.) Utrecht: Universiteit Utrecht.

Van Leeuwen, K. (I999). Het meten van opvoeding met de schaal voor ouderlijk gedrag. Diagnostiekwijzer, 4, I5I-I70.

Van Leeuwen, K. (2002). Beknopte handleiding voor het praktisch gebruik van de Schaal Ouderlijk Gedrag (SOG). Gent: Universiteit Gent.

Veerman, J. W., \& Yperen, T. A. van (2007). Degrees of freedom and degrees of certainty. A developmental model for the establishment of evidence-based youth care. Evaluation and Program Planning, 30, 2I2-22I.

Verhulst, F. C., Van der Ende, J., \& Koot, H. M. (I996). Handleiding voor de CBCL/4-18. Rotterdam: Sophia Kinderziekenhuis/Academisch ziekenhuis Rotterdam (Afdeling Kinder- en Jeugdpsychiatrie).

Verhulst, F. C., Van der Ende, J., \& Koot, H. M. (I997). Handleiding voor de Teacher's Report Form (TRF). Rotterdam: Sophia Kinderziekenhuis/Academisch ziekenhuis Rotterdam (Afdeling Kinder- en Jeugdpsychiatrie).

Walsh, F. (I998). Strengthening family resilience. New York: Guilford Press.

Webster-Stratton C., \& Hammond, M. (I997). treating children with early-onset conduct problems: A comparison of child and parent training interventions. Journal of Consulting and Clinical Psychology, 65, 93-Io9.

Webster-Stratton C., \& Taylor T. (200I). Nipping early risk factors in the bud: Preventing substance abuse, delinquency and violence in adolescence through interventions targeted at young children (o-8 years). Prevention Science, 2, 165-192. 